\title{
Examining the Problem Solving Skills of Primary Education Mathematics Teacher Candidates according to Their Learning Styles
}

\author{
Hasan Altun ${ }^{1}$ \\ ${ }^{1}$ European University of Lefke, Gemikonağı, TRNC via Mersin 10, Turkey \\ Correspondence: Hasan Altun, Assistant Professor, Department of Elementary School Mathematics Teacher \\ Education, Dr. Fazıl Küçük Education Faculty, European University of Lefke, Gemikonağı, TRNC via Mersin 10, \\ Turkey.
}

Received: November 22, 2018

doi:10.5539/ies.v12n4p60

\author{
Accepted: December 28, $2018 \quad$ Online Published: March 20, 2019 \\ URL: https://doi.org/10.5539/ies.v12n4p60
}

\begin{abstract}
In this study, it is aimed to investigate the problem solving skills of primary education mathematics teacher candidates according to their learning styles. The students of Primary Education Mathematics Department students of the universities in TRNC constitute the general universe of the research and the students who study in Primary Education Mathematics Department of a private university in TRNC constitute the universe of the study. Sampling of the research consists of a total 26 students studying in Primary Education Mathematics Department in 2017-2018 academic year, determined by using the appropriate sampling method.

In order to determine the learning styles of primary education mathematics teacher candidates, 12-item Kolb Learning Inventory, developed (1976) and rearranged (1985) by Kolb and the applicability of which was proven by Aşkar and Akkoyunlu (1993) in Turkey was used in this research. Problem solving inventory used to determine teacher candidates' problem solving skills was developed in 1982 by Heppner and Petersen and adapted to Turkish by Şahin, Şahin and Heppner.

As a result of the study, when students' learning styles are examined it was observed that the students with converging learning style are $42.3 \%$, students with assimilating learning style are $38.5 \%$, students with diverging learning style are $11.5 \%$ and students with an accommodating learning style are $7.7 \%$. It was observed that the students who participated in the study showed a tendency towards problem solving confidence. It has been suggested that taking learning styles and problem solving skills in organizing educational environments into account can help in increasing success.
\end{abstract}

Keywords: individual differences, Kolb's learning style inventory, problem, problem solving skills

\section{Introduction}

Great developments that has appeared in the field of technology during the last century has brought about some developments in the economy and social fields. These developments naturally led to some changes in the daily life of individuals. The change in the types of problems faced by individuals in daily life and the emergence of new problems are the leading events among these developments. It is seen that a situation that is a problem for an individual is no longer a problem. This has increased the importance of problem-solving skills that would improve the quality of life and enable individuals to adapt to the rapidly changing world. The problem word is Latin and comes from the root of "Problema". It varies according to the time, the situation in which the person is and it varies from person to person. When the literature about the problem concept is examined, it can be seen that there are many different definitions of the problem. The problem according to these definitions: A simple and complex process that consist of the factors that prevent the individual from reaching a goal that he wants to reach, or a problem that is difficult or unclear (Altun, 2002). While Karasar (2005) describes the problem as "uncertainty that discomforts the individual physically or intellectually and any situation with multiple solutions", Heppner and Krouskopf (1987, p. 391) expressed the problem as cognitive and effective behavioral processes of the individual for internal and external adaptation. This situation, which gives discomfort to the individual, brings the need for the individual to eliminate the problem, that is, the need to solve it. Fidan and Erden (1996) described problem solving as a cognitive and behavioral process in which the steps with a certain logical sequence were consciously followed. When the definition of problem solving examined, it can be summarized as a mental and physical process that involves the elimination of distress and finding solutions against the situation that appears and annoys. 
The individual should develop problem solving skills to solve the problem he encounters. Bandura (1986) stated that individuals whose problem-solving skills have improved reach their goals easier and carried out their jobs better. According to Erden (1996), gaining the problem-solving skills to individuals should be the priority of all educational institutions.

Individuals can learn in different ways due to their cognitive, linguistic motor and social skills (Schunk, 2009, p. 1). Many complex processes and experiences are effective in individual's learning. In this process, individual differences such as learning style, learning preference, learning strategy, cognitive style, thinking style are directly effective. The importance of individual differences increases in planning and implementation of teaching. Taking the individual differences into consideration by knowing beforehand will ease learning the information given for students. In a study supported by UNESCO (2004), it is stated that although individual differences affect educational environment, it is generally expected from students to learn in the same way in schools. One of the first to come to mind is the individual's learning style. The learning style is the method that the individual prefers to receive and process the information (Kolb, 1984, pp. 24-29; McCarthy, 1990, p. 31). Felder (1996) defines the concept of learning style as individual differences in the process of receiving and processing information, and in another different definition, learning styles are defined as how students learn more than what they learn (Hunt, 1979).

In the field of mathematics education, it is seen that many studies have been done to determine the learning styles of students. A significant part of the studies about learning style is towards determining the learning styles. In addition, it was seen that the relationship between the learning styles of the students and the variables such as gender, class level, discipline, mathematics achievement, attitudes towards mathematics course, and mathematics anxiety were examined. In his study, Çelik (2010, p. 77) aimed at determining the effect of cognitive style and learning styles of the primary education 7th grade students on the scores of different measurement formats (multiple choice test, written test and short response test). As a result of the study, it was found that there was a significant difference between the cognitive styles of students and their success scores from different measurement formats. In the study of Zengin and Alşahan (2012, p. 138) it was aimed to investigate the effect of teacher candidates' gender, high school that they studied, pre-school education level and socio-economic level of their family on their learning styles. Kolb's Learning Styles Inventory (1999) was used in the study. As a result of the study, it was found that demographic variables (high school, preschool education, mother education status, father's education status, mother profession and father's profession), except gender and the monthly income of the family, did not cause any differentiation to the learning styles of teacher candidates. Kolb's Learning Styles Inventory-III (1999) was used in the study of Kural (2009, p. 84) in which students' learning styles in science and technology course were examined according to academic success and socio-demographic characteristics. As a result of the study, it was found that the learning styles of the students did not differ according to gender and there was no significant difference between the students' learning styles and the socio-economic status of the school. In order to determine the learning styles of the students of Education Faculty, Mutlu (2005, p. 16) used Kolb's Learning Style Inventory (1985). As a result of the study, no significant difference was found between the learning styles of male and female students.

In his study, Gürsoy (2008, p. 108) investigated the learning styles of teacher candidates in terms of various variables. Kolb's Learning Styles Inventory-III (1999) was used as a data collection tool. According to the results of the research, it was found that the learning styles of the students did not differ significantly according to the gender; on the other hand, there was a significant difference according to the departments they studied.

When the studies on problem solving skills revised, in their study, Heppner, Reeder and Larson (1983, p. 540) examined the problem solving skills of university students in relation to various cognitive variables (self-conception, irrational beliefs and disfunctional thoughts). As a result of the study, a statistically significant relationship was found between all the dependent variables and their perception of problem solving skills. In the study by Korkut (2002, p. 179) that examined the problem solving skills of high school students, Problem Solving Inventory developed by Heppner and Petersen (1982) and the Personal Information Form prepared by the researcher were used. The students' problem solving skills were examined in terms of school type, age, gender, mother's education and work, father's education, job, sources of social support, and variables who understood their problems. As a result of the study, while it was seen that the variables gender, type of school, age, father's job, the individuals who speak and understand the problems of them affected their perception of problem solving skills, the variables mother's job and the parents' education did not affect the problem solving skills of the students. Düzakın (2004, p. 98) used Problem Solving Inventory developed by Heppner and Petersen's (1982) to investigate the problem solving skills of high school students in terms of parental attitude, type of school, grade level, number of siblings, number of births and gender. As a result of the study, it was 
found that the problem solving skills did not differ according to the mother attitude, but they differed according to the attitude of father. There was a significant difference in problem solving skills of the students in favor of Anatolian high school students. Problem-solving skills of female students were found higher.

When various studies examining problem-solving skill and learning style brought together, some of the studies can be summarised as follows. Louange (2007) determined the relationship between number sense, problem solving skills and learning-teaching styles of primary education students. Significant relationships were found between number sense and problem solving skills of students. It was seen that the teaching style was an important factor in improving the number sense and problem solving performance of the students. The relationship between learning styles and problem solving skills of physical therapy students was examined by Wessel et al. (1999: 23). As a result of the research, it was determined that most of the students had assimilating and converging learning styles. The problem solving skills and learning styles of students were found to be independent from the students' educational level in which they were studying. In the study conducted by Özer (2010), it was determined that the learning styles and problem solving skills of the 7th grade students did not differ according to the gender of the students. In the study conducted by Açı (2013), it was aimed to determine the learning styles and problem solving skills of high school students and to investigate the relationship between learning styles and problem solving skills of high school students in terms of various variables. It was found that there was a very weak positive relationship between the active experimentation learning style and the sub-dimension of problem-solving ability and the total score of problem solving skills. In the study conducted by Özgen and Alkan (2014), it was determined that learning activities suitable for learning styles of high school students increased the students' academic achievement and improved their problem solving skills within the context of constructivist learning approach. However, it was observed that the practice did not make a statistically significant difference in students' attitudes towards mathematics.

When the studies are examined, since the learning styles of the individuals are different, it is expected that their attitudes and behaviors towards the problems they face, the solution steps they produce for the solution of the problem and the ways they follow differ. Different strategies and models can be developed and used in the problem solving process resulting from the differences in learning styles of students and the structure of the problems; and different conclusions can be obtained from the results obtained. Because the student chooses appropriate alternative to his learning style and develops a suitable problem solving process for this. This situation can vary from individual to individual (Leng \& Hoo, 1997, p. 125). Furthermore, Klavir and Hershkovitz (2008) state that individual differences can be seen among students as a result of examining the problem solving process and that the analysis of these differences gives teachers the opportunity to evaluate the mathematical knowledge level of their students. Such evaluations can be made by examining and comparing students in each dimension of problem solving. Such a comparison can be useful in encouraging lower level students to develop their mathematical skills and maximizing their performance in a dimension in which they are good or in another different dimension. Therefore, especially in mathematics education, the differences in the problem solving skills of the individual in the problem solving process revealed the importance of determining learning style of the individual and the relationship between them.

When the studies are reviewed there are many theories about problem solving and learning styles. From these theories, Heppner problem solving process which is related to problem solving and David Kolb's Learning Style Model which is related to learning styles are described below.

\subsection{Heppner's Problem Solving Process}

Heppner (1988) explained the importance of problem solving methods of individuals in problem solving process in three basic approaches.

Problem Solving Confidence: It expresses an individual's belief and confidence that he/she will find effective solutions when he/she faces with a problematic situation. In short, it is the belief and confidence of an individual to his problem solving ability. In general, it can be said as self-efficacy of the individual about problem-solving ability (Şahin, Şahin, \& Heppner, 1993, p. 382).

Approach-Avoidance: It can be explained as the tendency to approach to or avoid form different problem solving activities. The low score indicates the approach to the problem and the high score indicates to avoid the problem. The tendency to approach to and avoid from the problem solving activity of the individual is very important. This situation directly affects the subsequent processes of problem solving activity such as defining the problem and finding solutions (Heppner \& Baker, 1997, p. 234).

Personal Control: It is explained as the belief of the individual in controlling the emotions and behaviors in the process of problem solving. This dimension includes two opposite dimensions, namely overreaction and control 
of behaviors (Heppner \& Baker, 1997, p. 235).

\subsection{David Kolb Learning Style Model}

The learning style model of David Kolb is based on the experiential learning model, which is based on the learning styles of people in the 1970s (Peker, 2003). In experiential learning model, thoughts can occur repeatedly through experience, and is constantly changing. The process is more important than the production; and the aim of the education is researching during the process of information acquisition and developing skills; it is not the memorization of information (Kolb, 1984). According to this model, there are two dimensions as grasping and transformation. The experiential learning model consists of two components related to the grasping of experience: Concrete Experience (CE) and Abstract Conceptualization (AC). There are also two components related to the transformation of experience: Reflective Observation (RO) and Active Experimentation (AE) (Star, 2011). In the Kolb learning style model, concrete experience and abstract conceptualization explain how an individual perceives information; reflective observation and active experience explain how the individual operates knowledge. That is, individuals perceive information by feeling or thinking, and process the information by watching or doing things. Kolb described the Experiential Learning Model as a four-stage cycle involving Concrete Experience-CE, Reflective Observation-RO, Abstract Conceptualization-AC, Active Experimentation-AE styles (Peker, 2003, cited in Y1ldiz, 2011). By combining these four learning styles, learning styles have been created (Kolb \& Kolb, 2005; Y1ld1z, 2011, p. 245). Kolb stated that each learning style (LS) combining with the other created new combinations; thus, more comprehensive learning styles were created. These learning styles are diverging LS, formed by $\mathrm{CE}$ and $\mathrm{RO}$; assimilating $\mathrm{LS}$, formed by $\mathrm{AC}$ and $\mathrm{RO}$; converging $\mathrm{LS}$, formed by $\mathrm{AE}$ and $\mathrm{AC}$; and accommodating LS, formed by AE and CE (Y1ldiz, 2011).

\subsection{David Kolb Learning Styles}

\subsubsection{Converging Learning Style}

It is a combination of abstract conceptualization and active life learning skills. Problem solving, decision making, logical analysis of ideas and systematic planning are the main features of those who has this learning style. Individuals in this learning style are successful in problem solving. Individuals make systematic planning when solving problems. Learning by doing is important. They are suited to professional models such as engineering, computer science, medical technology, agriculture and forestry, economics, environmental sciences (Aşkar \& Akkoyunlu, 1993).

\subsubsection{Diverging Learning Style}

Concrete experience and reflective observation is a combination of learning and learning abilities. The most important feature of people with this learning style is to be aware of their ability to think, values and meanings. They are the people who revise concrete situations in many ways and organize the relationships in a meaningful way. In the case of learning, they are patient, objective, careful judges, but not being in an action. While shaping thoughts, they take their own thoughts and feelings into consideration. They are suited to professional models such as various artistic fields, psychology, nursing, social studies, theater, literature, design, media and journalism (Aşkar \& Akkoyunlu, 1993).

\subsubsection{Assimilating Learning Style}

It is a combination of abstract conceptualization and reflective observation learning abilities. The most prominent feature of the people with this learning style is creating conceptual models. When they learn something, they focus on abstract concepts and ideas. They are committed to professional models such as physics, biology, mathematics, educational sciences, sociology, law, and theology (Aşkar \& Akkoyunlu, 1993).

\subsubsection{Accommodating Learning Style}

Concrete experience and active experimentation are a combination of their learning abilities. Planning, executing decisions and participating in new experiences are key features of the people with this learning style. In the case of learning, individuals are open-minded and they adapt to change easily. They are compatible with the areas such as management, public finance, education management, marketing, public administration, human resources etc (Aşkar \& Akkoyunlu, 1993).

\section{The Importance and Purpose of the Research}

Teachers often prefer a proper teaching style to their own learning styles as they do not know their students learning styles. Teaching environments organized according to students' learning styles increases the quality of education and increases the academic success of the students. Knowing the learning styles and problem solving skill levels of the students will contribute to the educational environments. It is thought that problem solving 
skills of students can be improved better by revealing the relationship between learning styles and problem-solving skills of the students and by implementing teaching methods suitable for their learning styles.

At the end of this research, findings obtained by determining and assessing the learning styles and problem solving skills of primary education mathematics teacher candidates who formed the study group and the suggestions to be developed in accordance with the findings will be able to contribute to the teachers in the way in which teachers increase the effectiveness of teaching learning processes and in which they communicate more easily with students. It is also thought that it can be useful for students in terms of learning how to learn and for future researches in terms of the possibility to increase scientific knowledge accumulation in the field.

The main aim of this study is to investigate the problem solving skills of primary education mathematics teacher candidates according to their learning styles. Through the purpose of the study, answers for the following sub-objectives were sought.

\subsection{Sub-Objectives}

1) What is the distribution of learning styles of primary education mathematics teacher candidates according to gender, high school type and graduation scores?

2) What is the level of problem solving skills of primary education mathematics teacher candidates?

3) Is there a statistically significant difference between the problem solving skills of the primary education mathematics teacher candidates according to their gender?

4) Is there a statistically significant difference between the problem solving skills of the primary education mathematics teacher candidates according to their learning styles?

5) Is there a statistically significant difference between the problem solving skills of the primary education mathematics teacher candidates according to the high school that they graduated?

6) Is there a statistically significant relationship between the academic achievement of primary education teacher candidates and their problem solving skills?

\section{Method}

\subsection{Research Design}

This study that aims to investigate problem solving skills of the primary education mathematics teacher candidates according to their learning styles is a descriptive study within the relational survey model. Survey models are research approaches that aim to describe a present or past situation as it exists. The event, individual or thing that is the subject of the research is tried to be defined in its own conditions and as is (Karasar, 2007, p. 77).

\subsection{Universe and Sampling}

The students of Primary Education Mathematics Department students of the universities in TRNC constitute the general universe of the research and the students who study in Primary Education Mathematics Department of a private university in TRNC constitute the universe of the study. Sampling of the research consists of total 26 students studying in Primary Education Mathematics Department in 2017-2018 academic year, determined by using appropriate sampling method. $73.1 \%(\mathrm{n}=19)$ of these students are female and $26.9 \%(\mathrm{n}=7)$ of them are males. The distribution of the students constituting the sample according to gender is given in Table 1 .

Table 1. The distribution of the students according to gender

\begin{tabular}{cccc}
\hline & & $\mathrm{N}$ & $\%$ \\
\hline \multirow{3}{*}{ Gender } & Male & 7 & 26.9 \\
& Female & 19 & 73.1 \\
& Total & 26 & 100.0 \\
\hline
\end{tabular}

\subsection{Data Collection Tool}

\subsubsection{Kolb's Learning Styles Inventory}

In this study, the third version of Kolb Learning Styles Inventory (KLSI-3) developed by David Kolb was used to determine learning styles of students. In the first version of the inventory, four words in nine lists are arranged to reveal the learning preferences of the individuals. The scores obtained from the scale are classified as diverger, 
assimilator, converger, and accommodator depending on learning preferences as concrete experience-CE, reflective observation- RO, abstract conceptualization- $\mathrm{AC}$, and active experimentation-AE according to Kolb's Experiential Learning Model (Kolb, 1984). The studies that have been done reveal that the reliability studies on this first version of the inventory should be continued. Inventory was renewed in 1985 by creating a new format and scoring system (Kolb and Kolb, 2005b). This second version of the inventory consists of 12 complementary type items. In order to increase the comprehensibility of the items, sentences were used instead of the words in the first version, and the statements were tried to be embodied. Surveys have shown that the reliability coefficient and internal consistency of the inventory are significantly higher than the previous version, and that it can be used to determine individuals' learning styles. This second version of the inventory was translated into Turkish by Aşkar and Akkoyunlu (1993), and validity and reliability studies were carried out. As a result of the studies, the reliability coefficients (Cranbach) of the four dimensions of the learning style inventory were found to vary between .73 and .83 . Accordingly, the reliability coefficient has been at the satisfactory level and it is concluded that KLSI can be applied in Turkey. In the research, the reliability of the inventory administered in order to determine the learning styles of the students was found to be between .72 and .83 .

\subsubsection{Problem Solving Inventory}

Problem solving inventory was developed in 1982 by Heppner and Petersen. The inventory was adapted to Turkish by Şahin, Şahin and Paul Heppner in 1993 and the Cronbach-Alfa value for the reliability of the scale was found as .88. The inventory is a self-evaluation scale and a tool for adolescent adults and evaluates what the individual thinks about problem-solving behavior and approaches. Therefore, it measures self-perception about problem solving skills. The inventory consisting of 35 items is a Likert type scale that is scored between 1 and 6 . The scale is easy to use and to score, there is no time limit for response, and the average response time is 15 minutes. When answering the questions, asking the question "How often do I do the behavior mentioned here?" to himself makes the inventory easier for the person. The inventory includes scoring of "1" I always act like this, "2" I mostly behave like this, "3" I often behave like this, "4" I behave like this occasionally, "5" I rarely behave like this, and "6" I never behave like this (Olgun, Kan-Öntürk, Karabacak, \& Eti-Aslan, 2010). The items consist of positive and negative judgments about problem solving and they are listed arbitrarily. Negative items $(1,2,3$, $4,11,13,14,15,17,21,25,26,30,34)$ were reversed in the scoring. Some items $(9,22,29)$ were excluded from scoring. With 32 items taken into consideration, the lowest score that can be taken from the scale is 32 and the highest score is 192. The high total scores obtained from the inventory indicate that the individual perceives himself / herself as inadequate in problem solving skills, and low scores indicate that the individual perceives himself / herself as sufficient in problem solving. The scale consists of three sub-dimensions. "Problem-solving Confidence" (PSC), which expresses the belief in one's ability to solve new problems, consists of these items: 5 , $10,11,12,19,23,24,27,33,34,35$. Problem "Approach-Avoidance Style" (AAS), which refers to the revision of initial problem-solving efforts for future implementations and active search for various alternative solutions, consists of these items 1, 2, 4, 6, 7, 8, 13, 15, 16, 17, 18, 20, 21, 28, 30, 31. The "Personal Control" (PC) dimension, which indicates the ability of individuals to maintain control over problematic situations, consists of these items: 13, 14, 25, 26, 27, 32 (Taylan, 1990).

\subsection{Analysis of Data}

The data obtained via Kolb's learning style inventory implemented to determine the students' learning styles and Problem Solving Inventory were analyzed by using the SPSS package program. Accordingly, from this descriptive statistical data; mean, standard deviation, frequency and percentage, ANOVA and t-test were used. The significance level in the study was accepted as 0.05 .

\section{Findings and Interpretations}

The distribution of learning styles of primary education school mathematics teacher candidates according to gender, high school and diploma grade are as follows.

The distribution of learning styles of primary education mathematics teacher candidates by gender is given in Table 2. 
Table 2. Percentage distribution of students' learning styles according to gender

\begin{tabular}{|c|c|c|c|c|c|}
\hline & & \multicolumn{2}{|c|}{ Gender } & \multirow[b]{2}{*}{$\mathrm{n}$} & \multirow[b]{2}{*}{$\%$} \\
\hline & & Male & Female & & \\
\hline \multirow{4}{*}{ Learning Style } & Converging & 4 & 7 & 11 & 42.3 \\
\hline & Assimilating & 3 & 7 & 10 & 38.5 \\
\hline & Accommodating & 0 & 2 & 2 & 7.7 \\
\hline & Diverging & 0 & 3 & 3 & 11.5 \\
\hline \multicolumn{2}{|c|}{ Total } & 7 & 19 & 26 & 100.0 \\
\hline
\end{tabular}

When Table 2 is examined, it is seen that the percentage of the students with converging learning style is $42.3 \%$; the percentage of the students with assimilating learning style is $38.5 \%$; the percentage of the students with diverging learning style is $11.5 \%$; and the percentage of the students with accommodating learning style is $7,7 \%$. When similar studies are examined, Güven (2003) studied the learning styles of teacher candidates in his thesis study named "Investigation of Learning Styles of Teacher Candidates in Physics Teaching". As a result of the research, it was seen that the physics teacher candidates prefer the "Converging" learning style. Denizoğlu (2008, p. 103) found in her study, called "The Assessment of the Relation Between Self-Efficacy Belief Levels, Learning Styles of Science Teacher Candidates towards Science Teaching and Their Attitudes towards Science Teaching", that science teacher candidates had mostly converging learning style. The concept of abstract conceptualization and active experimental learning forms the converging learning style (Aşkar \& Akkoyunlu, 1993). Therefore, it can be said that the students with converging learning style (42.3\%) preferred to learn by thinking and doing.

Baker, Simon and Bazeli (1987, p. 223) were the first researchers to use the Kolb Learning Styles Inventory-II version to examine the learning styles of university students. As a result of the research, it was seen that a large group of students (44\%) preferred assimilating learning style. Jenkins and Holley (1991, p. 47) examined the learning styles of accounting students. The study group consisted of total 98 students, 46 of whom were male and 52 of whom were female students. Research findings showed that both male and female students preferred the assimilating learning style.

It is seen that all of the students with diverging learning style are female students. The most obvious features of this learning style are that they are aware of their ability to think, values, and meanings (Aşkar \& Akkoyunlu, 1993). In this case, it can be said that female students' thinking abilities are higher than male students.

It is seen that all of the students with the accommodating learning style are female students. Accommodating learning style is the combination of concrete and active experimental learning styles, and it can be stated that $7.6 \%$ of the students with accommodating learning style prefer to learn by feeling and doing. The most prominent features of this learning style are planning, making decisions and taking part in new experiences (Aşkar \& Akkoyunlu, 1993).

The distribution of primary education mathematics teacher candidates' learning styles according to the high schools they graduated from is given in Table 3.

Table 3. Distribution of students' learning styles according to the high schools graduated

\begin{tabular}{cccccc}
\hline & & \multicolumn{3}{c}{ Schools Graduated } \\
\cline { 3 - 6 } & & $\begin{array}{c}\text { Anatolian High } \\
\text { School }\end{array}$ & $\begin{array}{c}\text { Anatolian } \\
\text { Teacher High } \\
\text { School }\end{array}$ & Basic High School & $\begin{array}{c}\text { Vocational High School of } \\
\text { Health }\end{array}$ \\
\cline { 3 - 6 } Learning Style & Converging & 8 & 0 & 3 & 0 \\
& Assimilating & 8 & 0 & 0 & 1 \\
& Accommodating & 1 & 0 & 1 & 0 \\
\hline
\end{tabular}

When Table 3 is examined, it is thought that primary education mathematics teacher candidates mostly graduated from Anatolian high schools and basic high schools.

The distribution of learning styles of primary education mathematics teacher candidates according to their grades is given in Table 4. 
Table 4. Distribution of learning styles according to the graduation scores

\begin{tabular}{|c|c|c|c|c|}
\hline & & \multicolumn{2}{|c|}{ Graduation Score } & \multirow[t]{2}{*}{ Toplam } \\
\hline & & $70-84$ & $85-100$ & \\
\hline \multirow{4}{*}{ Learning Style } & Converging & 8 & 3 & 11 \\
\hline & Assimilating & 8 & 2 & 10 \\
\hline & Accommodating & 2 & 0 & 2 \\
\hline & Diverging & 1 & 2 & 3 \\
\hline \multicolumn{2}{|c|}{ Total } & 19 & 7 & 26 \\
\hline
\end{tabular}

When Table 4 is examined, it is seen that the graduation scores of the primary education mathematics teacher candidates, who have converging, assimilating and diverging learning styles are within the range of 85 to 100 points.

4.1 The First Sub-Objective of The Research Was Expressed as "What Is the Level of Problem Solving Skills of Primary Education Mathematics Teacher Candidates?"

In order to determine the problem solving skill levels of primary education mathematics teacher candidates, the score means of "Problem Solving Inventory" and the sub-dimensions were taken into consideration. The 6-point Likert evaluation scale is divided into 6 equal parts as it is from 1 to 6 , and the mean score corresponding to each option is determined. In the interpretation of the range between 1.00-1.83 was evaluated as "I always behave like this"; the range between 1.84-2.66 was evaluated as "I mostly behave like this"; the range between 2.67-3.49 was evaluated as "I often behave like this"; the range between 3.50-4.32 was evaluated as "I occasionally behave like this"; the range between $4.33-5,15$ was evaluated as "I rarely behave like this"; and the range between 5.16 and 6.00 was evaluated as "I never behave like this".

Primary education mathematics teacher candidates' mean and standard deviation values of problem solving skill levels and sub-dimensions are given in Table 5.

Table 5. Mean and standard deviation scores of problem solving skills dimensions

\begin{tabular}{lcccc}
\hline Problem Solving Skills Dimensions & $\mathrm{n}$ & $\overline{\mathrm{X}}$ & $\mathrm{ss}$ & Response Level \\
\hline Problem Solving Confidence & 26 & 4.430 & .675 & Rarely \\
Approach-Avoidance & 26 & 4.134 & .536 & Occasionally \\
Personal Control & 26 & 3.583 & .629 & Occasionally \\
Problem Solving Skill & 26 & 3.827 & .356 & Rarely \\
\hline
\end{tabular}

When Table 5 is examined, the problem solving confidence dimension of the students participating in the research shows a tendency towards "rarely". The students have tendency towards "Occasionally" in terms of approach-avoidance and personal control dimensions. As a result, it can be said that students' problem-solving skills have tendency towards "Occasionally".

4.2 The Second Sub-Objective of The Study Was Expressed as "Is There a Statistically Significant Difference Between the Problem Solving Skills of the Primary Education Mathematics Teacher Candidates According to Their Gender?"

Mean, standard deviations, $\mathrm{p}$ and $\mathrm{t}$ values of problem solving skills and sub-dimensions of primary education mathematics teacher candidates are given in Table 6. 
Table 6. Mean, standard deviations, $\mathrm{p}$ and values of problem solving skills and sub-dimensions of primary education mathematics teacher candidates

\begin{tabular}{|c|c|c|c|c|c|c|c|}
\hline & Gender & $\mathrm{n}$ & Mean & Std. Deviation & $\begin{array}{c}\text { Std. Error } \\
\text { Mean }\end{array}$ & $\mathrm{t}$ & $\mathrm{p}$ \\
\hline \multirow{2}{*}{ Problem Solving Skills } & Male & 7 & 3.800 & .373 & .141 & \multirow{2}{*}{-.149} & \multirow{2}{*}{.886} \\
\hline & Female & 19 & 3.824 & .360 & .082 & & \\
\hline \multirow{2}{*}{ Problem Solving Confidence } & Male & 7 & 4.506 & .811 & .306 & \multirow{2}{*}{.344} & \multirow{2}{*}{.766} \\
\hline & Female & 19 & 4.401 & .641 & .147 & & \\
\hline \multirow{2}{*}{ Approach-Avoidance } & Male & 7 & 4.071 & .439 & .166 & \multirow{2}{*}{.316} & \multirow{2}{*}{.690} \\
\hline & Female & 19 & 4.157 & .577 & .132 & & \\
\hline \multirow{2}{*}{ Personal Control } & Male & 7 & 3.476 & .494 & .186 & \multirow{2}{*}{.447} & \multirow{2}{*}{.556} \\
\hline & Female & 19 & 3.622 & .680 & .156 & & \\
\hline
\end{tabular}

When the Table 6 investigated, as a result of the one-way analysis of variance applied to the data, in order to determine whether there is a statistically significant difference between the problem solving and sub-dimensions according to the gender of primary education mathematics teacher candidates, the problem solving skills and sub-dimensions of the students according to their gender did not show a statistically significant difference. The studies in the literature that support and do not support the results obtained in this study are given below.

Taylan (1990, p. 45) conducted adaptation, reliability and validity studies of Heppner's problem solving skills inventory. As a result of the study, it was determined that the total score of the inventory of the problem solving did not differ significantly according to the gender of the students. In the study of Korkut (2002, p. 179) conducted a study with 394 high school students by investigating their problem solving skills. As a result of the research, it was observed that gender variable affected the perception of problem solving skills. Düzakın (2004, p. 98) found out that female students' problem solving skills were higher in a study aiming at investigating the problem solving skills of high school students in terms of some variables. In their study, Genç and Kalafat (2007, p. 18) aimed at evaluating the teacher candidates' democratic attitudes and problem solving skills in terms of various variables. As a result of the research, it was revealed that there was no significant difference between the teacher candidates' problem solving skills and gender. Finally, Demirtaş and Dönmez (2008, p. 195) aimed to investigate the problem solving skills of teachers working in secondary education in terms of some variables. There was no statistically significant difference between the perceptions of teachers about problem solving skills according to gender variable.

4.3 The Third Sub-Objective of the Study Was Expressed as "Is There a Statistically Significant Difference Between the Problem Solving Skills of the Primary Education Mathematics Teacher Candidates According to Their Learning Styles?"

Table 7. "ANOVA" result of students' learning styles and sub-dimensions of problem solving skills

\begin{tabular}{|c|c|c|c|c|c|c|}
\hline & & Sum of Squares & df & Mean Square & $\mathrm{F}$ & Sig. \\
\hline \multirow{3}{*}{ Problem Solving Skill } & Between Groups & .120 & 3 & .040 & .287 & .834 \\
\hline & Within Groups & 3.064 & 22 & .139 & & \\
\hline & Total & 3.184 & 25 & & & \\
\hline \multirow{3}{*}{ Problem Solving Confidence } & Between Groups & .677 & 3 & .226 & .463 & .711 \\
\hline & Within Groups & 10.737 & 22 & .488 & & \\
\hline & Total & 11.414 & 25 & & & \\
\hline \multirow{3}{*}{ Approach-Avoidance } & Between Groups & .724 & 3 & .241 & .821 & .496 \\
\hline & Within Groups & 6.469 & 22 & .294 & & \\
\hline & Total & 7.193 & 25 & & & \\
\hline \multirow{3}{*}{ Personal Control } & Between Groups & .297 & 3 & .099 & .227 & .877 \\
\hline & Within Groups & 9.606 & 22 & .437 & & \\
\hline & Total & 9.903 & 25 & & & \\
\hline
\end{tabular}

When Table 7 is examined; no statistically significant difference between Problem Solving Skills olarak scale and sub-dimensions, and learning style independent variable was found. In short, it does not affect students' learning styles and problem solving skills in a significant way. The studies that support and do not support the 
results obtained in the literature are given below. Wessel et al. (1999, p. 23) examined the relationship between learning styles and problem solving skills of physical therapy students. As a result of the research, no relationship was found between the students' problem solving skills and learning styles. In his study, Uysal (2010, p. 151) aimed to determine the effect of cooperative learning on students' achievement, problem solving skills and learning styles in primary education social studies teaching and to determine the views of students about cooperative learning. At the end of the study, the scores of the experimental group and the control group that they got from problem solving skills inventory before and after the experiment were compared, and it was determined that there was a significant difference in favor of the experimental group. In addition, it was found that cooperative learning did not lead to a differentiation in students' learning styles. It was observed that academic contradiction technique from cooperative learning methods had a positive effect on problem solving skills of students with cooperative and competitive learning style. Udeani and Adeyoma (2011, p. 86) examined the relationship between teachers' problem-solving skills and their learning styles and academic achievement in biology. As a result of the research, a positive relationship was found between the problem solving skills of the teachers and the learning styles of the students. Mohamad, Heong, Rajuddin, and Keong (2011, p. 44) aimed to determine the relationship between learning styles and problem solving skills of construction vocational school students. According to the research results, a significant relationship was found between the learning styles and problem solving skills of the students of construction vocational high schools.

4.4 The Fourth Sub-Objective of the Study Was Expressed As "Is There a Statistically Significant Difference Between the Problem Solving Skills of the Primary Education Mathematics Teacher Candidates According to The High School That They Graduated?"

ANOVA results related to the sub-dimensions of the problem solving skills of the primary education mathematics teacher candidates according to the school that they graduated are given in Table 8 .

Table 8. ANOVA results related to the sub-dimensions of the problem solving skills of the students according to the high school that they graduated

\begin{tabular}{|c|c|c|c|c|c|c|}
\hline & & Sum of Squares & $\mathrm{df}$ & Mean Square & $\mathrm{F}$ & Sig. \\
\hline \multirow{3}{*}{ Problem Solving Skill } & Between Groups & .543 & 4 & .136 & 1.079 & .392 \\
\hline & Within Groups & 2.641 & 21 & .126 & & \\
\hline & Total & 3.184 & 25 & & & \\
\hline \multirow{3}{*}{ Problem Solving Confidence } & Between Groups & 3.160 & 4 & .790 & 2.010 & .130 \\
\hline & Within Groups & 8.255 & 21 & .393 & & \\
\hline & Total & 11.414 & 25 & & & \\
\hline \multirow{3}{*}{ Approach - Avoidance } & Between Groups & .845 & 4 & .211 & .699 & .601 \\
\hline & Within Groups & 6.347 & 21 & .302 & & \\
\hline & Total & 7.193 & 25 & & & \\
\hline \multirow{3}{*}{ Personal Control } & Between Groups & 2.090 & 4 & .523 & 1.405 & .267 \\
\hline & Within Groups & 7.812 & 21 & .372 & & \\
\hline & Total & 9.903 & 25 & & & \\
\hline
\end{tabular}

As is seen in Table 8; when "the Problem Solving Skills" scale and its sub-dimensions were examined according to the independent variable that is high school from which the students graduated, no statistically significant difference was found. In short, graduated school type does not significantly affect the students' problem solving skills.

Korkut (2002, p. 179) investigated the problem solving skills of high school students. In the data collection, the Problem Solving Inventory developed by Heppner and Petersen (1982) and the Personal Information Form prepared by the researcher were used. As a result of the research, it was seen that school type variable affected their perception of problem solving skills. Düzakın $(2004$, p. 98) examined the problem solving skills of high school students in terms of some variables. Research data were gathered by using Problem Solving Inventory developed by Heppner and Petersen (1982). As a result of the research, it was seen that the problem solving skills differed significantly in favor of the students studying at Anatolian High School. As a result of the study conducted by Demirtaş and Dönmez (2008, p. 195) on problem solving skills of teachers working in secondary education, it was determined that teachers' perceptions about problem solving skills of themselves were statistically significant according to the last school type of graduation. 
4.5 The Fifth Sub-Objective of the Study Was Expressed as "Is There a Statistically Significant Relationship Between the Academic Achievement of Primary Education Teacher Candidates and Their Problem Solving Skills?"

The result of Pearson product-moment correlation coefficient related to academic achievement and problem-solving skills of primary education mathematics teacher candidates are given in Table 9.

Table 9. "Pearson Product-Moment Correlation Coefficient Analysis Results" in relation to students' academic achievements and problem solving skills

\begin{tabular}{|c|c|c|c|c|c|}
\hline & & $\begin{array}{c}\text { Problem Solving } \\
\text { Confidence }\end{array}$ & $\begin{array}{c}\text { Approach-Avoidanc } \\
\mathrm{e}\end{array}$ & Personal Control & $\begin{array}{c}\text { Problem Solving } \\
\text { Skills }\end{array}$ \\
\hline \multirow{3}{*}{ Approach-Avoidance } & $\mathrm{r}$ & .097 & & & \\
\hline & $\mathrm{p}$ & .639 & & & \\
\hline & $\mathrm{n}$ & 26 & & & \\
\hline \multirow{3}{*}{ Personal Control } & $\mathrm{r}$ & .086 & .276 & & \\
\hline & $\mathrm{p}$ & .675 & .172 & & \\
\hline & $\mathrm{n}$ & 26 & 26 & & \\
\hline \multirow{3}{*}{ Problem Solving Skills } & $\mathrm{r}$ & $.637^{* *}$ & $.786^{* *}$ & $.458^{*}$ & \\
\hline & $\mathrm{p}$ & .000 & .000 & .019 & \\
\hline & $\mathrm{n}$ & 26 & 26 & 26 & \\
\hline \multirow{3}{*}{ Graduation Score } & $\mathrm{r}$ & -.059 & .072 & -.083 & -.018 \\
\hline & $\mathrm{p}$ & .775 & .728 & .688 & .929 \\
\hline & $\mathrm{n}$ & 26 & 26 & 26 & 26 \\
\hline
\end{tabular}

Although there is not a common range for the correlation coefficients in terms of relationship level; the correlation coefficient between 0.00-0.29 can be interpreted as low relationship; between 0.30-0.70 can be interpreted as moderate relationship, and greater than 0.70 can be interpreted as high relationship (Büyüköztürk, 2016). No statistically significant relationship between the academic achievement of the students and the sub-dimensions of problem solving skill scale (Problem Solving-Guidance, Approach-Avoidance, Personal Control) or overall scale-general was found.

Yalçın, Tetik, and Açikgöz (2010, p. 25) in their study in which they determined the perception of problem solving ability and locus of control levels of high school students and they examined their relationship with some variables, it was found that students' perception of themselves as academically successful was an important factor in problem solving skills and locus of control. Özsoy (2005) examined the relationship between the problem solving skills and mathematics achievement of 107 students studying at the 5th grade of two primary schools in two branches. As a result of the research; it was found that there was a significant and positive relationship between $5^{\text {th }}$ grade mathematics achievement and problem solving skills.

\section{Conclusion and Suggestions}

As a result of this research; it was observed that the learning styles of primary education mathematics teacher candidates differed. It was determined that the students mostly have diverging and assimilating learning style. Problem solving confidence dimension of the students who participated in the study showed a tendency towards "rarely". Students tend to have "occasionally" trend with regard to approach-avoidance and personal control dimensions. It was determined that, in general, students' problem solving skills presented a tendency towards "occasionally". It was seen that problem solving skills and their sub-dimensions of primary education teacher candidates posed no statistically significant difference according to their gender. When students were examined according to "Problem Solving Skills Scale" and its sub-dimensions and the independent variable, learning style, no statistically significant difference was observed. In short, students' learning styles do not affect problem solving skills significantly. When the Problem Solving Skills Scale and its sub-dimensions examined according to the independent variable, graduated high school type, it was found that there was not any statistically significant difference. Statistically significant difference was not determined between the academic achievement and the sub-dimensions of problem solving skills scale (Problem Solving Confidence, Approach-Avoidance, Personal Control) and general scale overall.

In the context of this study and in the light of the findings related to learning styles and problem solving skills;

- It can be said that taking individual differences into account will increase the efficiency of education and 
teaching of students.

- Since learning style and problem-solving skills are unique to the individual, it is thought that having been known by students, teachers and parents, these characteristics of the students will be beneficial.

- It is thought that choosing maths problems that are appropriate for students' learning styles in the mathematics course will contribute to the students' problem solving skills.

- It may be useful to determine the learning environment in the students' learning style change and problem solving skills in certain periods of education.

This study examining learning styles and problem solving skills can be applied to larger groups of students. It is recommended to do research at primary and high school level in which the effect of learning style and problem solving skills on mathematics and geometry teaching, which is not covered in this study.

\section{References}

Açık, S. (2013). Lise ögrencilerinin ögrenme stilleri ve problem çözme becerileri arasindaki iliş̧kinin incelenmesi. Yayımlanmamıs yüksek lisans tezi, Abant Izzet Baysal Üniversitesi, Bolu.

Altun, M. (2000). İlköğretimde Problem Çözme Öğretimi. Milli Egütim Dergisi, 147.

Altun, M. (2002). Matematik Öğretimi (10 Baskı). Bursa: Alfa.

Aşkar, P., \& Akkoyunlu, P. (1993). Kolb Öğrenme Stili Envanteri, Egĭtim ve Bilim, 87, 37-47.

Baker, R. E., Simon, J. R., \& Bazeli, F. P. (1987). Selecting instructional design for introductory accounting based on the experiential learning model. Journal of Accounting Education, 5, 207-226. https://doi.org/10.1016/0748-5751(87)90019-4

Bandura, A. (1986). Social Foundations of Thought and Action A Social Cognitive Theory. New Jersey: Prentice-Hall, Inc. Englewood Cliff

Büyüköztürk, Ș., Çakmak, K. E., Akgün, O. E., Karadeniz, Ş., \& Demirel, F., (2016). Bilimsel araștırma yöntemleri. Ankara: Pegem Akademi.

Çelik, T. (2010). Ilkögretim ögrencilerinin bilișsel stil ve ögrenme stillerinin farklı ölçme formatlarından aldıkları puanlara etkisi. Yayınlanmamış yüksek lisans tezi, Bolu: Abant Izzet Baysal Üniversitesi Sosyal Bilimler Enstitüsü.

Demirtaş, H., \& Dönmez, B. (2008). Ortaöğretimde görev yapan öğretmenlerin problem çözme becerilerine ilişkin algıları. Inönü Üniversitesi Egĭtim Fakültesi Dergisi, 16(9), 177-198.

Denizoğlu, P. (2008). Fen bilgisi ögretmen adaylarının fen bilgisi ögretimi öz-yeterlik inanç düzeyleri, ögrenme stilleri ve fen bilgisi ögretimine yönelik tutumları arasindaki ilișkinin değerlendirilmesi. Yayınlanmamış yüksek lisans tezi, Adana: Çukurova Üniversitesi Sosyal Bilimler Enstitüsü.

Düzakın S. (2004). Lise ögrencilerinin problem çözme becerilerinin bazı degĭskenler açısından incelenmesi, . Yayınlanmamıs yüksek lisans tezi, Ankara: Gazi Üniversitesi Eğitim Bilimleri Enstitüsü.

Erden, M. (1996). Sosyal Bilgiler Öğretimi. Pegem yayınc1lık: İstanbul

Felder, R. M. (1996). Matters of Style. ASEE Prism, 6(4), 18-23.

Fidan, N., \& Erden, M. (1998). Egĭtime Giriș, İstanbul: Alkım Yayınları.

Genç, Z. S., \& Kalafat, T. (2007). Öğretmen adaylarının demokratik tutumları ile problem çözme becerilerinin çeşitli değişkenler açısından incelenmesi. Pamukkale Üniversitesi Egütim Fakültesi Dergisi, 22(2), 10-22.

Gürsoy, T. (2008). Ögřetmen adaylarının ögrenme stillerinin çeșitli degĭșenler açısından incelenmesi. Yayınlanmamış doktora tezi, Aydın: Adnan Menderes Üniversitesi Sosyal Bilimler Enstitüsü.

Güven, G. (2003). Fizik Ögretiminde Ögřetmen Adaylarının Ögrenme Stillerinin Araştırllması, Yüksek lisans tezi, Marmara Üniversitesi, Fen Bilimleri Enstitüsü, Istanbul.

Heppner P. P., \& Krauskopf, C. J. (1987). An information processing approach to personal problem solving. The Counseling Psychologist, 15(3), 371-447. https://doi.org/10.1177/0011000087153001

Heppner, P. P., \& Baker, C. E. (1997). Application of the problem solving inventory. Measurement and Evaluation in Counseling and Development, 29(4), 229-313.

Heppner, P. P., \& Petersen, C. H. (1982). The development and implications of a personal problem-solving inventory. Journal of Counseling Psychology, 29(1), 66-75. https://doi.org/10.1037/0022-0167.29.1.66 
Heppner, P. P., Reeder, B. L., \& Larson, L. M. (1983). Cognitive variables associated with personal problem-solving appraisals implications for counseling. Journal of Counseling Psychology, 30, 537-545. https://doi.org/10.1037/0022-0167.30.4.537

Hunt, D. E. (1979). Learning style and student needs: an introduction to conceptual level, student learning styles: diagnosing and prescribing programs. Reston, VA: National Association of Secondary School

Jenkins, E. K., \& Holley, J. H. (1991). Learning style preferences and the prospective accountant: Are there gender differences? The Woman CPA, Fall, 46-49.

Karasar, N. (2005). Bilimsel Araștırma Yöntemi. Nobel Yayınları, 15. Baskı Ankara

Karasar, N. (2007). Bilimsel araştırma yöntemi (17. Bask1). Ankara: Nobel.

Klavir, R., \& Hershkovitz, S. (2008). Teaching and Evaluating “Open-Ended” Problems. International Journal for Mathematics Teaching and Learning. Retrieved from http://www.cimt.plymouth.ac.uk/journal/default. htm

Kolb, A. Y., \& Kolb, D. A. (2005). Learning styles and learning spaces: Enhancing experiental clearning in higher education. Academy of Management Learning\& Education, 4(2), 193-212. https://doi.org/10.5465/amle.2005.17268566

Kolb, D. A. (1984). Experiential learning: experiences as the source of learning and development. Englewood Cliffs, N.J.: Prentice-Hall.

Korkut, F. (2002). Lise öğrencilerinin problem çözme becerileri. Hacettepe Üniversitesi Egütim Fakültesi Dergisi, $22,177-184$.

Kural, H. (2009). Ögrencilerin ögrenme stillerinin fen ve teknoloji dersi akademik bașarılarına ve sosyo-demografik özelliklerine göre incelenmesi. Yayınlanmamış yüksek lisans tezi, Aydın: Adnan Menderes Üniversitesi Sosyal Bilimler Enstitüsü.

Leng, Y. L., \& Hoo, C. T. (1997). Exploring the Thinking, Learning Styles and Cognition Constructs. The Mathematics Educator, 2(1), 113-127.

Louange, J. E. G. (2007). An examination of the relationships between teaching and learning styles, and the number sense and problem solving of year 7 students. Yayınlanmamıs doktora tezi, Edith Cowan University, Perth Western Australia.

McCarthy, B. (1990). Using the 4Mat system to bring learning styles to schools. Educational Leadership, 48(2), 31-37.

Mohamad, M. M., Heong, Y. M., Rajuddin, M. R., \& Keong, T. T. (2011). Identifying relationshıp involving learning styles and problem solving skills among vocational students. Journal of Technical Education and Training (JTET), 3(1), 37-45.

Mutlu, M. (2005). Öğrenme stillerine dayalı fen bilgisi öğretimi. Yüzüncüyll Üniversitesi Egĭtim Fakültesi Dergisi, 2(2), 1-24.

Olgun, N., Kan-Ontürk, Z., Karabacak, U., \& Eti-Aslan, F. (2010). Hemşirelik öğrencilerinin problem çözme becerileri: Bir yıllık izlem sonuçları. Acıbadem Universitesi Saglık Bilimleri Dergisi, 1, 188-194.

Özer, D. (2010). Ilkögretim 7. sını ögrencilerinin ögrenme stilleri ile problem çözme becerileri arasındaki ilişskinin incelenmesi. Yayımlanmamış yüksek lisans tezi, Mehmet Akif Ersoy Üniversitesi, Burdur.

Özgen, K., \& Alkan, H. (2014). Yapılandırmacıöğrenme yaklaşımı kapsamında, öğrencilerin öğrenme stillerine uygun öğrenme etkinliklerinin akademik başarı ve tutuma etkileri: fonksiyon ve türev kavramı örneklemesi. Turkish Journal of Computer and Mathematics Education, 5(1), 1-38. https://doi.org/10.16949/turcomat.35299

Özsoy, G. (2005). Problem Çözme Becerisi ile Matematik Başarısı Arasındaki İlişki. Gazi Üniversitesi Eğitim Fakiltesi Dergisi, 3, 179-190

Peker, M. (2003). Kolb Öğrenme Modeli. Milli Ĕ̆itim Dergisi, 157.

Şahin, N., Sahin, N. H., \& Heppner, P. P. (1993). Psychometric properties of the problem solving inventory in a group of Turkish University Students. Cognitive Therapy and Research, 17(4), 379-396. https://doi.org/10.1007/BF01177661

Schunk, D. H. (2009). Ögřenme Teorileri Egütimsel Bir Bakıș (Çev. Ed. M. Șahin). Ankara: Nobel Yayın 
Dağıtım.

Taylan, S. (1990). Heppner’in Problem Çözme Envanteri’nin Uyarlama. Güvenirlik ve Geçerlik Çalışmaları. Yayımlanmamış Yüksek Lisans Tezi, Ankara: Ankara Üniversitesi Sosyal Bilimler Enstitüsü.

Udeani, U., \& Adeyemo, S. A. (2011). The relationship among teachers problem solving abilities, student's learning styles and students achievement in biology. International Journal of Educational Research and Technology, 2(1), 82-87

Uysal, G. (2010). Ilkögretim sosyal bilgiler dersinde işbirlikli ögrenmenin erișiye, problem çözme becerilerine, ögrenme stillerine etkisi ve ögrenci görüssleri. Yayınlanmamış Doktora Tezi, Izmir: Dokuz Eylül Üniversitesi Eğitim Bilimleri Enstitüsü.

Wessel, J., Loonis, J., Rennie, S., Brook, P., Hoddinott, J., \& Aherne, M. (1999). Learning styles and perceived problem-solving ability of students in a baccalaureate physiotherapy programme. Physiotherapy Theory and Practice, 15(1), 17-24. https://doi.org/10.1080/095939899307865

Yalçın, B., Tetik, S., \& Açıkgöz A. (2010). Yüksekokul öğrencilerinin problem çözme becerisi algıları ile kontrol odağı düzeylerinin belirlenmesine yönelik bir araștırma. Organizasyon ve Yönetim Bilimleri Dergisi, 2(2), 19-27.

Yıldız, H. (2011). Öğretim ilke ve yöntemleri (VI. Bölüm). İstanbul: İdeal Kültür ve Yayıncılık.

Zengin, R., \& Alşahan, Ö. L. (2012). Öğretmen adaylarının öğrenme stillerinin bazı değişkenler açısından değerlendirilmesi. e-Journal of New World Sciences Academy, 7(1), 133-140.

\section{Copyrights}

Copyright for this article is retained by the author(s), with first publication rights granted to the journal.

This is an open-access article distributed under the terms and conditions of the Creative Commons Attribution license (http://creativecommons.org/licenses/by/4.0/). 